Jurnal Penelitian Pendidikan Geografi Volume 3 No. 1 Januari 2018

\title{
PENERAPAN MODEL PEMBELAJARAN GENERATIF UNTUK MENINGKATKAN HASIL BELAJAR GEOGRAFI SISWA KELAS X2 SMA NEGERI 2KULISUSU PADA METERI POKOK LITOSFER
}

\author{
Hasrianti $^{1}$, La Ode Nursalam ${ }^{2}$ \\ 1;2 Program Studi Pendidikan Geografi, Universitas Halu Oleo, Kendari.
}

\begin{abstract}
Abstrak: Masalah yang diteliti adalah: 1) Gambaran aktivitas belajar siswa 2) Gambaran aktivitas mengajar guru 3) Peningkatan hasil belajar. Penelitian bertujuan untuk 1) Mengetahui gambaran aktivitas belajar siswa, 2) Mengetahui gambaran aktivitas mengajar guru. 3) Mengetahui peningkatan hasil belajar. Jenis penelitian adalah Penelitian Tindakan Kelas (PTK) yang telah dilaksanakan 2 siklus. Subyek penelitian ini siswa yang terdaftar pada semester genap tahun pelajaran 2016/2017 berjumlah 36 orang. Data penelitian ini adalah aktivitas mengajar guru dan aktivitas belajar siswa diperoleh dari lembar observasi dan hasil belajar yang diukur melalui tes. Analisis data yang dilakukan adalah statistic deskriptif. Hasil penelitian menunjukkan bahwa: 1) Aktivitas belajar pada setiap siklus cenderung meningkat. Hal ini ditunjukkan dengan skorrata-rata pada setiap siklus, pada siklusI skor rata-rata aktivitas siswa adalah 2,8 meningkat pada siklusII menjadi 3,4. 2) pada siklusI skor rata-rata aktivitas mengajar guru adalah 2,9 meningkat pada siklusII menjadi 3,7. 3) Hasil belajar geografi ditingkatkan melalui model pembelajaran generatif. Pada siklusI siswa yang tuntas 26(72,2\%) dan tidak tuntas dan tidak tuntas $10(27,8 \%)$ dengan rata-rata 72,63 sedangkan pada siklus kedua meningkat menjadi 32 (89\%) siswa yang tuntas dan 4(11\%) siswa tidak tuntas rata-rata 82,36.
\end{abstract}

\section{Kata kunci: Model Pembelajaran, Proses, Hasil Belajar}

\section{PENDAHULUAN}

Permasalahan mengenai hasil belajar siswa yang masih rendah sampai saat ini masih selalu melanda dunia pendidikan yang belum bisa di nyatakan secara pasti penyebab hal tersebut apakah dari kemampuan mengajar yang dimiliki oleh tenaga pengajar yang masih kurang atau motivasi belajar dari siswa sendiri yang masih rendah.

Melihat perkembangan dan kemajuan era modern pada saat ini sangat memungkinkan terjadinya peningkatan hasil belajar siswa. Namun fakta yang terjadi hasil belajar siswa justru sering tidak memenuhi standar ketuntasan yang telah ditetapkan disuatu sekolah. Sekolah merupakan tempat penyelenggaraan pendidikan yang memiliki peranan dalam menciptakan manusia yang berkualitas, tidak terlepas dari peranan guru dalam mengembangkan kemampuan yang telah dimilikinya.

Guru merupakan ujung tombak yang cukup berperan dalam menentukan kualitas lulusan karena guru berinteraksi langsung dengan siswa selama kegiatan proses pembelajaran. Penyelenggaraan pembelajaran merupakan kunci utama dalam meningkatkan kualitas pembelajaran. Salah satu indikator untuk menilai kualitas pendidikan adalah hasil belajar yang dicapai oleh siswa di sekolah.

Hasil belajar siswa dapat ditingkatkan apabila pembelajaran berlangsung secara efektif dan efisien dengan ditunjang oleh tersedianya sarana dan prasarana pendukung serta kecakapan guru dalam mengelola proses pembelajaran. Proses pembelajaran yang diterapkan disekolah khususnya untuk mata pelajaran geografi seharusnya dapat 
mendorong siswa untuk aktif, berpikir kritis, dan dapat bekerja sama dengan siswa lainnya.

Proses pembelajaran yang cocok diterapkan agar dapat mendorong keaktifan siswa adalah dengan model pembelajaran generatif, dimana dalam proses pembelajaran dengan model ini guru tidak hanya sekedar mentransfer materi kepada siswa, namun guru memiliki empat peranan penting yaitu : stimulator rasa ingin tahu siswa, mambangkitkan dan menantang ide-ide siswa, sebagai narasumber, dan sebagai senior co-investigator sehingga siswa akan selalu dihadapkan pada permasalahan-permasalahan yang akan merangsang dan melatihnya untuk aktif berfikir. Untuk meningkatkan mutu pengajaran Geografi diperlukan peningkatan kualitas para pendidik. Semata-mata bukan hanya penyusunan kembali kurikulum yang lebih sempurna, melainkan pembenahan kembali pendekatan, metode yang tepat dengan memperhatikan mata pelajaran, fasilitas dan kondisi siswa sebagai subyek didik yakni motivasi belajar yang dimiliki, minat, ketekunan dan karakteristik materi dan siswa sehingga dalam penggunaan model pembelajaran tidak harus sama untuk semua pokok bahasan.

Berdasarkan hasil observasi dan wawancara singkat pada guru geografi dikelas X2 SMA Negeri 2 Kulisusu pada tanggal 18 Juli 2016, diperoleh informasi bahwa sebagian besar hasil belajar siswa dikelas tersebut masih rendah. Selama dua tahun terakhir ini menunjukan bahwa data hasil belajar geografi siswa kelas X2 semester ganjil tahun ajaran 2014/2015 yang terdiri dari 27 orang siswa, yang memperoleh nilai $\geq 70$ hanya 13 orang siswa atau 48,15\%, sedangkan siswa yang memeperoleh nilai $<70$ sebanyak 14 orang siswa atau sekitar 51,85\%. Dan pada tahun ajaran 2015/2016 yang terdiri dari 36 orang siswa yang memperoleh nilai $\geq 70$ hanya 20 orang siswa atau
$55,56 \%$, sedangkan siswa yang memperoleh nilai $<70$ sebanyak 15 orang siswa atau sekitar 44,44\%. Nilai dari kedua tahun ajaran tersebut masih tergolong rendah dari nilai KKM untuk mata pelajaran Geografi yaitu 70 (KTSP).Perolehan skor hasil belajar geografi siswa pada tahun pelajaran 2014/2015 dan 2015/2016 tersebut diatas menunjukan adanya hasil belajar siswa yang kurang baik.

Menurut Tytler (Hulukati, 2005:60), model pembelajaran generatif merupakan salah satu model yang dapat diterapkan dalam suatu pembelajaran yang terdiri dari empat fase pembelajaran yaitu fase eksplorasi pendahuluan (preliminary), fase pemusatan (focus), fase tantangan (challenge), serta fase aplikas (application). Pelaksanaan pembelajaran dengan model pembelajaran ini pada dasarnya diawali dengan mengkontruksi pengetahuan dalam pembelajaran. Setelah mengkontruksi siswa menginterpretasi informasi yang diperoleh tersebut kemudian membuat kesimpulan. Sehingga siswa akan terbiasa untuk membangun pengetahuan dan ideidenya sendiri.

\section{METODE PENELITIAN}

Penelitian ini dilaksanakan pada semester genap tahun ajaran 2016/2017 bertempat di SMA Negeri 2 Kulisusu kelas X2. subyek penelitian ini adalah siswa kelas X2 SMA Negeri 2 Kulisusu tahun ajaran 2016/2017 yang berjumlah 36 Orang yang terdiri dari 16 Orang perempuan dan 12 Orang laki-laki. Jenis penelitian ini adalah Penelitian Tindakan Kelas (PTK), Penelitian tindakan kelas adalah suatu pencermatan terhadap kegiatan belajar berupa tindakan, yang sengaja dimunculkan dan terjadi dalam sebuah kelas secara bersama (Suharsimi Arikunto,2006): 3). Faktor yang diselidiki yaitu: 1) Faktor siswa 2) Faktor guru. Penelitian tindakan kelas ini 
dilaksanakan sebanyak dua siklus dengan tiap siklus dilaksanakan sesuai dengan perubahan yang ingin dicapai pada faktorfaktor yang diteliti.

Desain model penelitian tindakan kelas (PTK) ini terdiri atas 4 (empat) tahap, yakni : perencanaan, pelaksanaan tindakan, pengamatan dan refleksi. Instrumen penelitian ini terdiri atas tiga jenis, yaitu:1) Tes hasil belajar, 2) Lembar observasi. Teknik analisis data dalam penelitian ini dianalisis dengan menggunakan analisis statistik deskriptif. Indikator keberhasilan dalam penelitian ini terdiri dari indikator keterlaksanaan skenario pembelajaran dan indikator peningkatan hasil belajar siswa.
Pelaksanaan tindakan kelas ini dipandang berhasil apabila sudah memenuhi kriteria keberhasilan yaitu : 1) Segi proses penelitian tindakan kelas ini dikatakan berhasil jika rata-rata aktivitas siswa telah memperoleh minimal 3,0, rata-rata aktivitas guru memperoleh minimal 3,0 2) dari segi hasil minimal $80 \%$ dari siswa secara klasikal memiliki nilai minimal sesuai `dengan $\mathrm{KKM}$ adalah $\geq 70$.

\section{HASIL PENELITIAN}

Data Aktivitas Siswa Siklus I

Data skor aktivitas belajar siswa dalam kegiatan belajar mengajar pada Siklus I dapat dilihat pada tabel 3.1 berikut

Tabel 3.1 Skor Rata-rata Aktivitas Siswa pada Setiap Siklusnya.

\begin{tabular}{|c|c|c|c|c|}
\hline \multirow{2}{*}{ No } & \multirow{2}{*}{ Aktivitas Siswa Yang Dinilai } & \multicolumn{3}{|c|}{ Skor/Siklus I } \\
\hline & & Pert. I & Pert. II & Rata-rata \\
\hline 1 & $\begin{array}{l}\text { Siswa mendengarkan dan memperhatikan guru } \\
\text { menyampaikan tujuan pembelajaran }\end{array}$ & 2,8 & 3 & 2,9 \\
\hline 2 & $\begin{array}{l}\text { Siswa mendengarkan/memperhatikan guru } \\
\text { mengenai materi pelajaran yang disampikan }\end{array}$ & 3 & 3,5 & 3,25 \\
\hline 3 & $\begin{array}{l}\text { Siswa mencari kelompok masing-masing yang } \\
\text { telah dibagi oleh guru }\end{array}$ & 3 & 3,2 & 3,1 \\
\hline 4 & $\begin{array}{l}\text { Siswa memperhatikan penjelasan guru } \\
\text { mengenai LKS yang telah dibagikan. }\end{array}$ & 2,5 & 3 & 2,75 \\
\hline 5 & $\begin{array}{l}\text { Siswa berdiskusi dengan kelompoknya dalam } \\
\text { menyelesaikan soal pada LKS }\end{array}$ & 2 & 3 & 2,5 \\
\hline \multirow[t]{2}{*}{6} & $\begin{array}{llll}\text { Siswa } & \text { bekerja } & \text { sama } & \text { dengan }\end{array}$ & & & \\
\hline & $\begin{array}{l}\text { anggotakelompoknya dalam menyelesaikansoal } \\
\text { pada LKS }\end{array}$ & 3 & 2,8 & 2,9 \\
\hline 7 & $\begin{array}{l}\text { Siswa bekerjasama dalam menyiapkan laporan } \\
\text { hasil diskusi kelompok }\end{array}$ & 2,6 & 2,6 & 2,6 \\
\hline 8 & $\begin{array}{l}\text { Siswa menyimak dan menanggapi hasil diskusi } \\
\text { kelompok lain }\end{array}$ & 2,8 & 2,8 & 2,8 \\
\hline 9 & $\begin{array}{l}\text { Siswa menunjukan antusiasme / minat terhadap } \\
\text { kegiatan pembelajaran dengan mengajukan } \\
\text { pertanyaan atau umpan balik Siswa }\end{array}$ & 2,4 & 2,6 & 2,5 \\
\hline 10 & $\begin{array}{l}\text { Menyimak penguatan dan koreksi dari guru } \\
\text { tentang hasil diksusi kelompok }\end{array}$ & 2,2 & 2,6 & 2,4 \\
\hline \multicolumn{2}{|c|}{ Rata-rata aktivitas siswa } & 2,6 & 2,9 & 2,8 \\
\hline \multicolumn{2}{|c|}{ Kategori } & & \multicolumn{2}{|c|}{ Cukup } \\
\hline
\end{tabular}


Jurnal Penelitian Pendidikan Geografi Volume 3 No. 1 Januari 2018

Gambaran rata-rata aktivitas belajar siswa dengan menerapkan model pembelajaran generatif pada siklus I

untuk setiap satuan aktivitas belajar yang dinilai dapat dilihat pada Gambar 3.1 berikut:

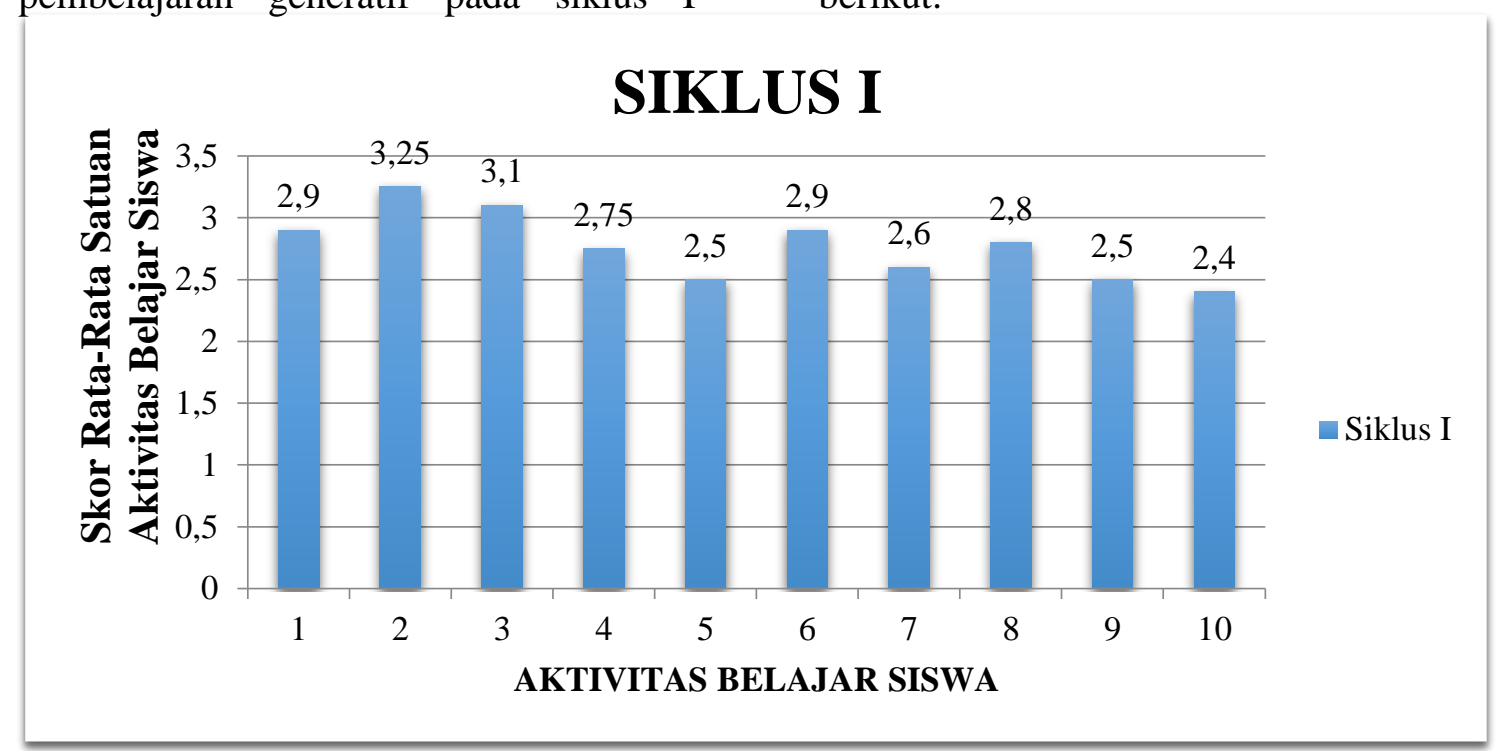

Gambar 3.1. Grafik Skor Rata-rata Satuan Aktivitas Belajar Siswa Siklus 1

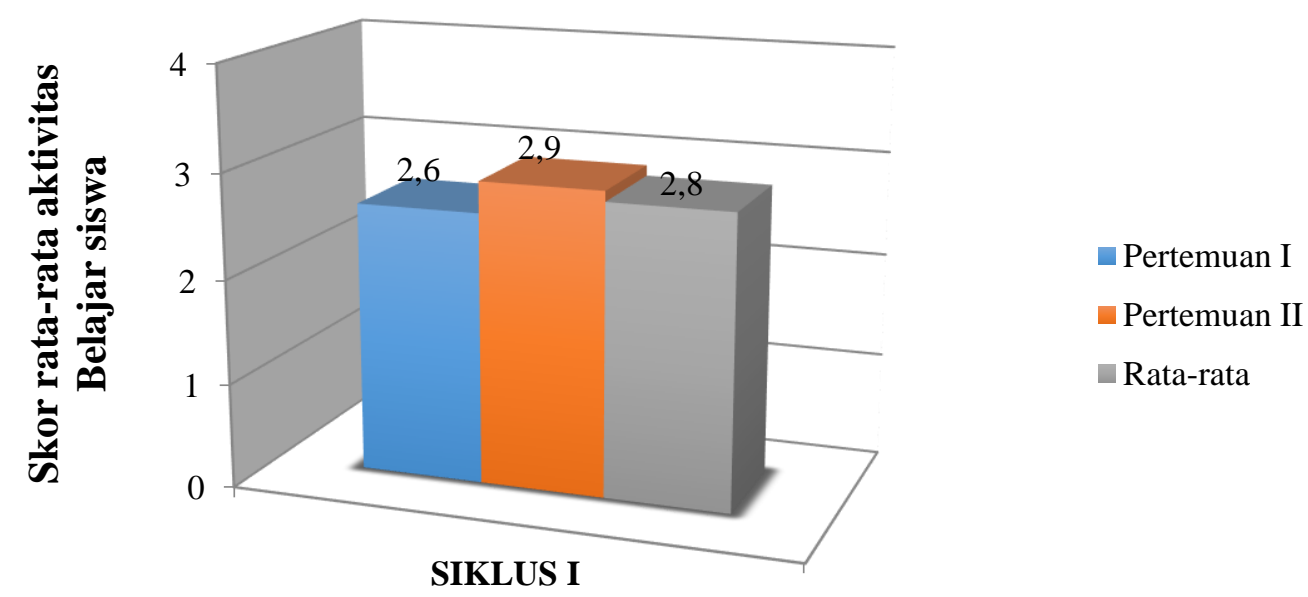

Gambar 3.2. Grafik Skor Rata-rata Aktivitas Belajar Siswa Siklus I

Data Aktivitas Guru Siklus I

Gambaran aktivitas guru dalam mengelola pembelajaran dengan menggunakan model pembelajaran

generatif diperoleh dengan menggunakan lembar observasi aktivitas guru pada siklus I dapat dilihat pada tabel 3.2 berikut :

\begin{tabular}{ccccc}
\multicolumn{6}{c}{ Tabel 3.2. Skor Rata-rata Aktivitas Guru Siklus I } \\
\hline \multicolumn{1}{c}{ Aspek Yang Dinilai } & Pert. I & Pert. II & $\begin{array}{c}\text { Rata- } \\
\text { Rata }\end{array}$ \\
\cline { 3 - 5 } No & $\begin{array}{c}\text { A. Kegiatan Pendahuluan } \\
1 . \quad \begin{array}{c}\text { Guru membuka pelajaran } \\
\text { memeriksa kesiapan siswa }\end{array}\end{array}$ & 4 & 4 & 4 \\
\hline 1 & dan & & & \\
\hline
\end{tabular}


Jurnal Penelitian Pendidikan Geografi Volume 3 No. 1 Januari 2018

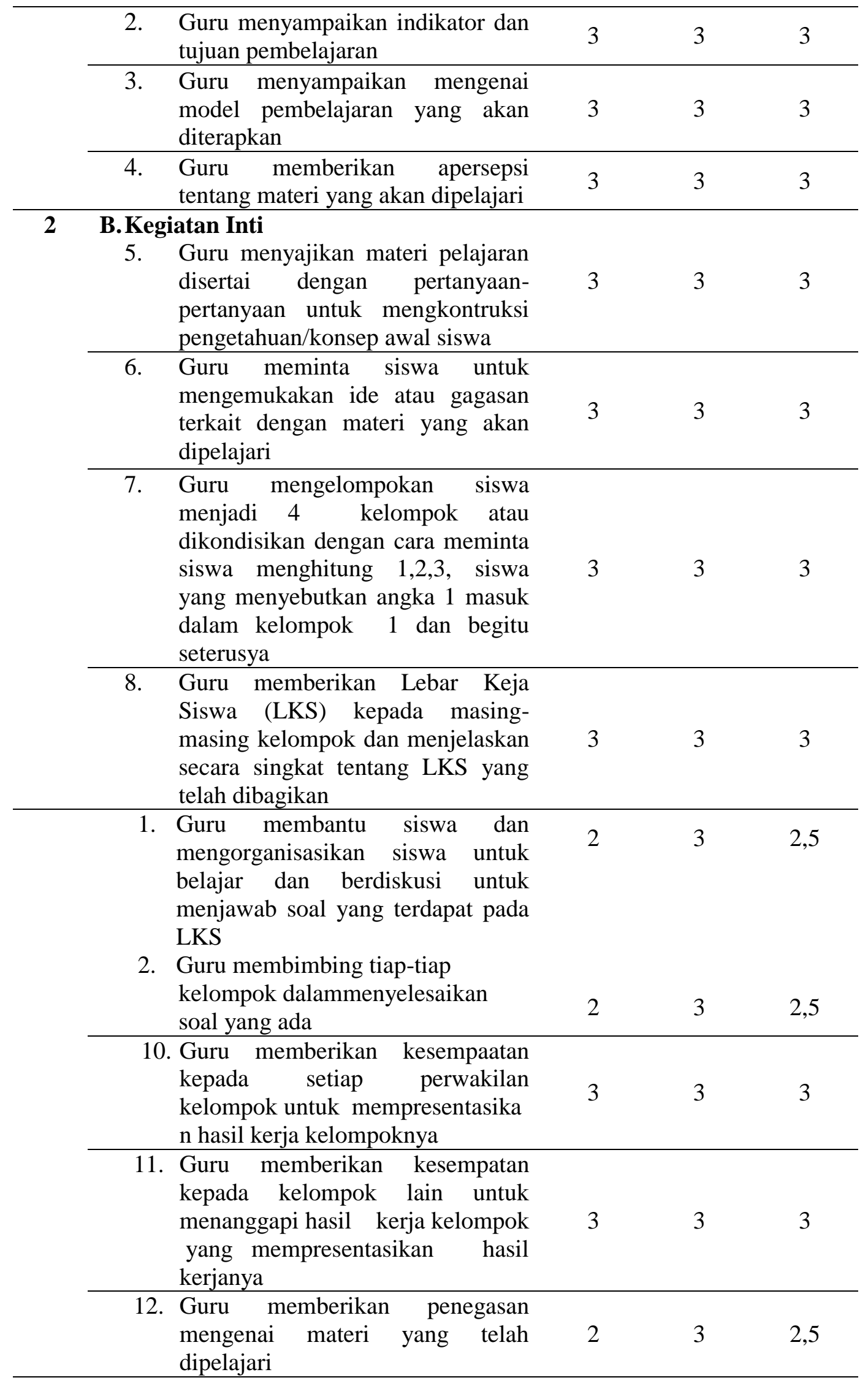


Jurnal Penelitian Pendidikan Geografi Volume 3 No. 1 Januari 2018

13. Guru memberikan reward berupa pujian kepada kelompok tanpa melihat benar atau salah konsep

$\begin{array}{lll}2 & 3 & 2,5\end{array}$
yang dikemukakan oleh siswa

\section{C. Kegiatan Akhir}

14. Guru memberikan kesempatan kepada siswa untuk bertanya mengenai materi yang kurang dimengerti

15. Guru bersama sama menyimpulka $n$ materi yang telah dibahas

16. Guru memberikan PR terkait

dengan materi yang diajarkan

$\begin{array}{lll}2 & 3 & 2,5\end{array}$

2

$3 \quad 2,5$

3

$3 \quad 3$

17. Guru menutup proses pembelajaran

4

4

4

\begin{tabular}{lccc}
\hline Rata-rata aktivitas guru & 2,8 & 3,1 & 2,9 \\
\hline Kategori & & & Cukup \\
\hline
\end{tabular}

Sumber:Data Diolah (2017)

Gambaran rata-rata aktivitas guru dengan menerapkan model pembelajaran aktivitas yang dinilai dapat dilihat pada generatif pada siklus I untuk setiap satuan

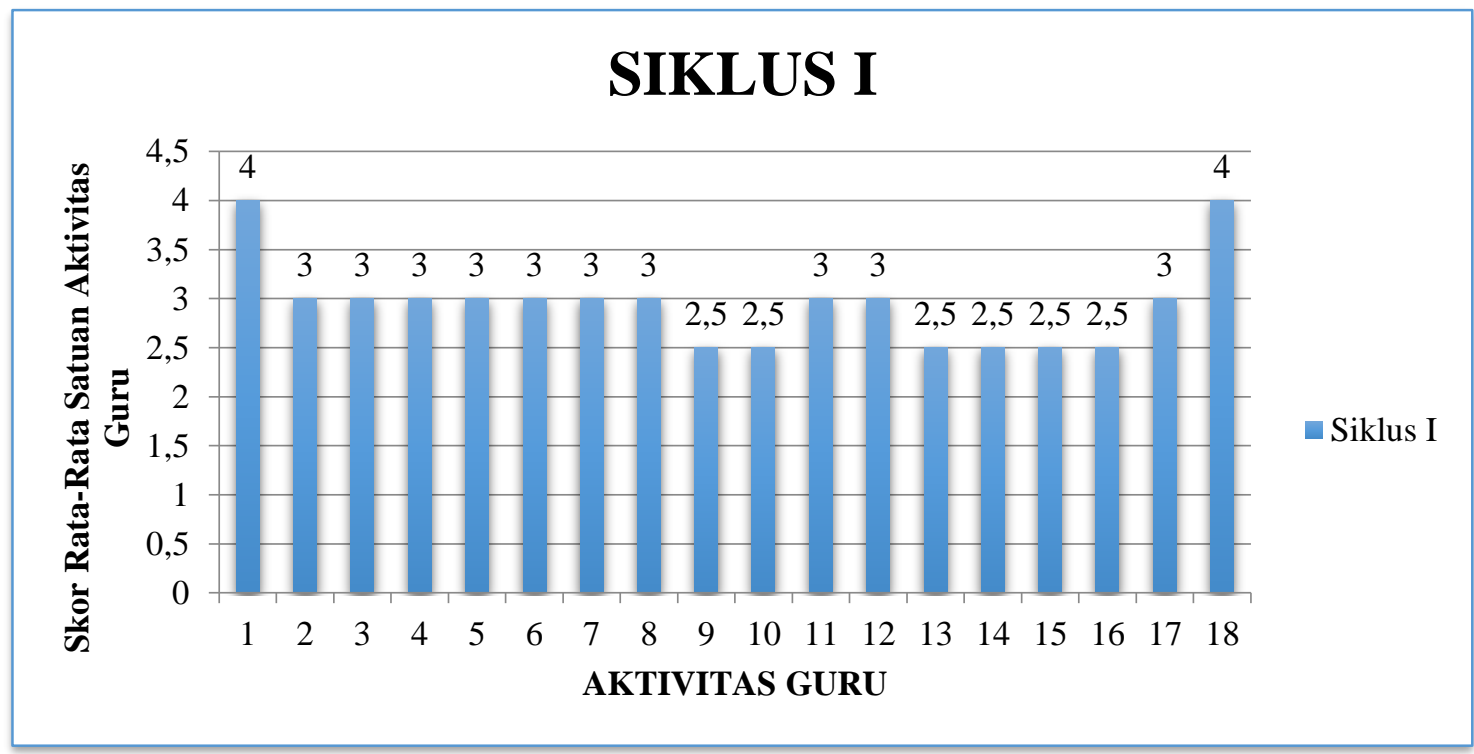

Gambar 3.3. Grafik Skor Rata-rata Satuan Aktivitas Guru Siklus I

Untuk mendapatkan gambaran rata-rata aktivitas guru selama pembelajaran pada siklus I pada pertemuan I dan II dapat dilihat pada Gambar 3.4 berikut : 
Jurnal Penelitian Pendidikan Geografi Volume 3 No. 1 Januari 2018

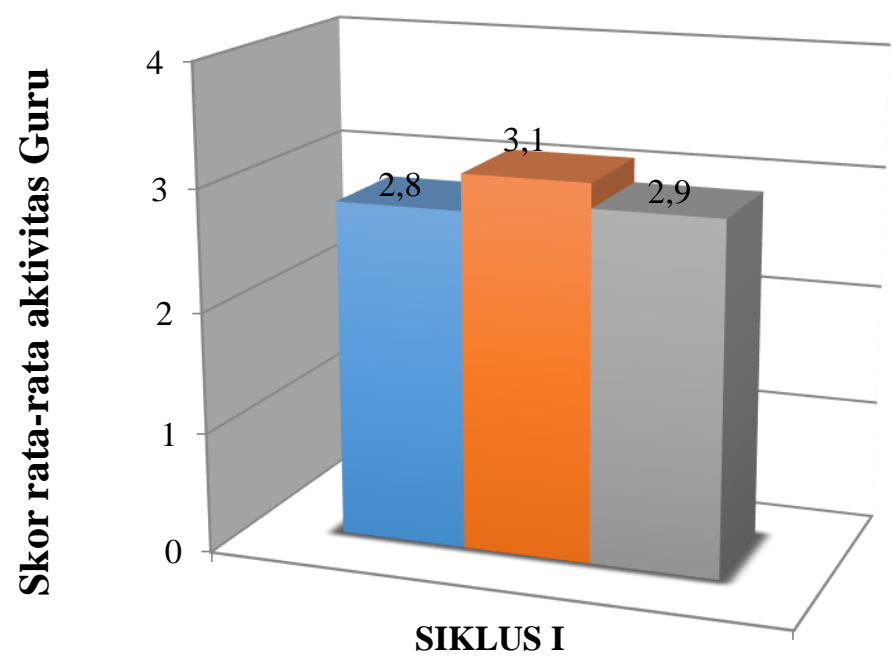

- Pertemuan I

- Pertemuan II

- Rata-rata

\section{Gambar 3.4. Grafik Skor Rata-rata Aktivitas Guru Siklus I}

\section{Data Hasil Belajar Siswa Siklus I}

Berdasarkan analisis data hasil

sebagaimana disajikan pada tabel 3.3 belajar siswa pada siklus I diperoleh hasil berikut :

Tabel 3.3. Data Analisis Ketuntasan Hasil Belajar Siswa Siklus I

\begin{tabular}{lccc}
\hline \multicolumn{1}{c}{ Skor } & Jumlah siswa & Presentase & Ketuntasan Belajar \\
\hline $0-69$ & 10 orang & $28 \%$ & Belum Tuntas \\
\hline $70-100$ & 26 orang & $72 \%$ & Sudah Tuntas \\
\hline Jumlah & $\mathbf{3 6}$ orang & $\mathbf{1 0 0 \%}$ & \\
\hline Keterangan $:$ & & & \\
\hline Tidak Tuntas & $\mathbf{: 1 0}$ orang & & \\
\hline Tuntas & $\mathbf{: 2 6}$ orang & & \\
\hline Nilai Rata-rata & $\mathbf{: 7 2 , 6 3}$ & \\
\hline Nilai Maksimum & $\mathbf{: 9 0}$ & \\
\hline Nilai Minimum & $\mathbf{: 5 0}$ & \\
\hline Presentase Ketuntasan $: \mathbf{7 2} \%$ & \\
\hline Sumber: Data Diolah $(2017)$
\end{tabular}

Untuk lebih jelasnya mengenai gambaran hasil belajar siswa kelas X2 yang diajar dengan menggunakan model pembelajaran generatifpada siklus I dapat dilihat pada gambar 3.5 berikut: 
Jurnal Penelitian Pendidikan Geografi Volume 3 No. 1 Januari 2018

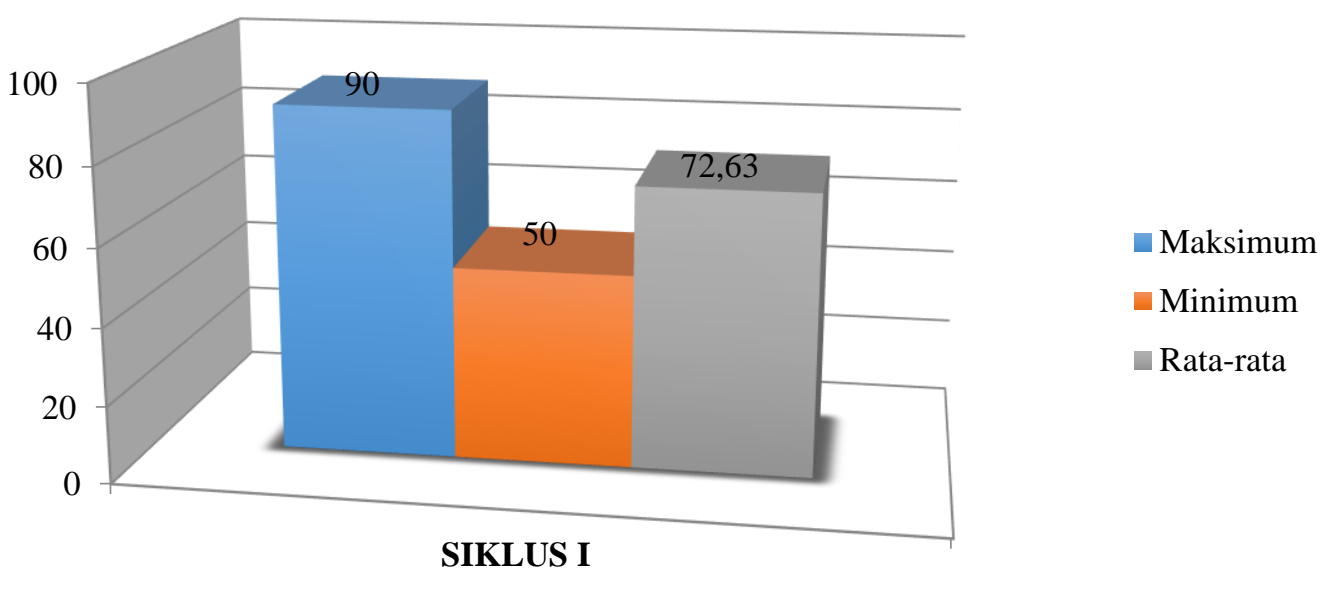

Gambar 3.5. Grafik Nilai Hasil Belajar Siklus I

Selanjutnya berdasarkan analisis diperoleh hasil sebagaimana disajikan ketuntasan belajar siswa pada siklus I pada gambar 3.6 berikut:

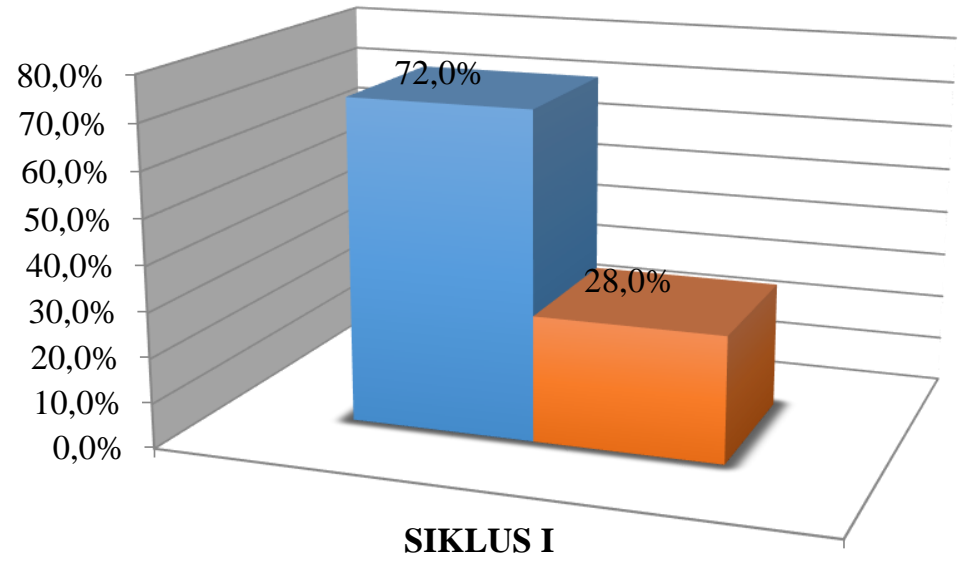

- Sudah Tuntas

- Belum Tuntas

Gambar 3.6. Grafik Presentase Ketuntasan Siswa Siklus I

Hasil Analisis Data Siklus II

Data Aktivitas Belajar Siswa Siklus II

Data skor aktivitas belajar siswa

dalam kegiatan belajar mengajar pada siklus II dapat dilihat pada tabel 3.5 berikut:

Tabel 3.4 Skor Rata-rata Aktivitas Belajar Siswa Siklus II

\begin{tabular}{ccccc}
\hline \multirow{2}{*}{ No } & \multirow{2}{*}{ Aktivitas Belajar Siswa Yang Dinilai } & \multicolumn{3}{c}{ Skor/Siklus II } \\
\cline { 3 - 5 } & Siswa Mendengarkan dan memperhatika & Pert. I & Pert. II & Rata-rata \\
\hline 1 & $\begin{array}{l}\text { n Guru menyampaikan tujuan Pembelaja } \\
\text { ran }\end{array}$ & 3,2 & 3,6 & 3,4 \\
\hline
\end{tabular}




\begin{tabular}{cllll}
\hline 2 & $\begin{array}{l}\text { Siswa mendengarkan/memperhatikan } \\
\text { guru mengenai materi pelajaran yang } \\
\text { disampikan }\end{array}$ & 3,5 & 3,5 & 3,5 \\
\hline 3 & $\begin{array}{l}\text { Siswa mencari kelompok masing-masing } \\
\text { yang telah dibagi oleh guru }\end{array}$ & 3,4 & 3,2 & 3,3 \\
\hline 4 & $\begin{array}{l}\text { Siswa memperhatikan penjelasan guru } \\
\text { mengenai LKS yang telah dibagikan. }\end{array}$ & 3 & 3,4 & 3,2 \\
\hline 5 & $\begin{array}{l}\text { Siswa berdiskusi dengan kelompoknya } \\
\text { dalam menyelesaikan soal pada LKS }\end{array}$ & 3,2 & 3,2 & 3,2 \\
\hline 6 & Siswa bekerja sama dengan anggota & 3,4 & 3,8 & 3,6 \\
\hline & $\begin{array}{l}\text { kelompoknya dalam menyelesaikan } \\
\text { soal pada LKS }\end{array}$ & 3,4 & 3,8 & 3,6 \\
\hline 7 & $\begin{array}{l}\text { Siswa bekerjasama dalam menyiapkan } \\
\text { laporan hasil diskusi kelompok }\end{array}$ & 3,2 & 3,4 & 3,3 \\
\hline 8 & $\begin{array}{l}\text { Siswa menyimak dan menanggapi hasil } \\
\text { diskusi kelompok lain }\end{array}$ & 3,4 & 3,6 & 3,5 \\
\hline 9 & $\begin{array}{l}\text { Siswa menyimak penguatan dan koreksi } \\
\text { dari guru tentang hasil diksusi kelompok }\end{array}$ & 3,2 & 3,8 & 3,5 \\
\hline 10 & $\begin{array}{l}\text { Siswa menunjukan antusiasme / minat } \\
\text { terhadap kegiatan pembelajaran dengan } \\
\text { mengajukan pertanyaan atau umpan } \\
\text { balik kepada guru }\end{array}$ & 3,2 & 3,4 & 3,3 \\
\hline
\end{tabular}

Rata-rata aktivitas siswa 3,3 3,5 3,4 Kategori Baik Sumber: Data Diolah (2017)

Gambaran rata-rata aktivitas belajar siswa dengan menerapkan model pembelajaran generatif pada siklus II untuk setiap satuan aktivitas belajar yang dinilai dapat dilihat pada gambar 3.7 berikut:

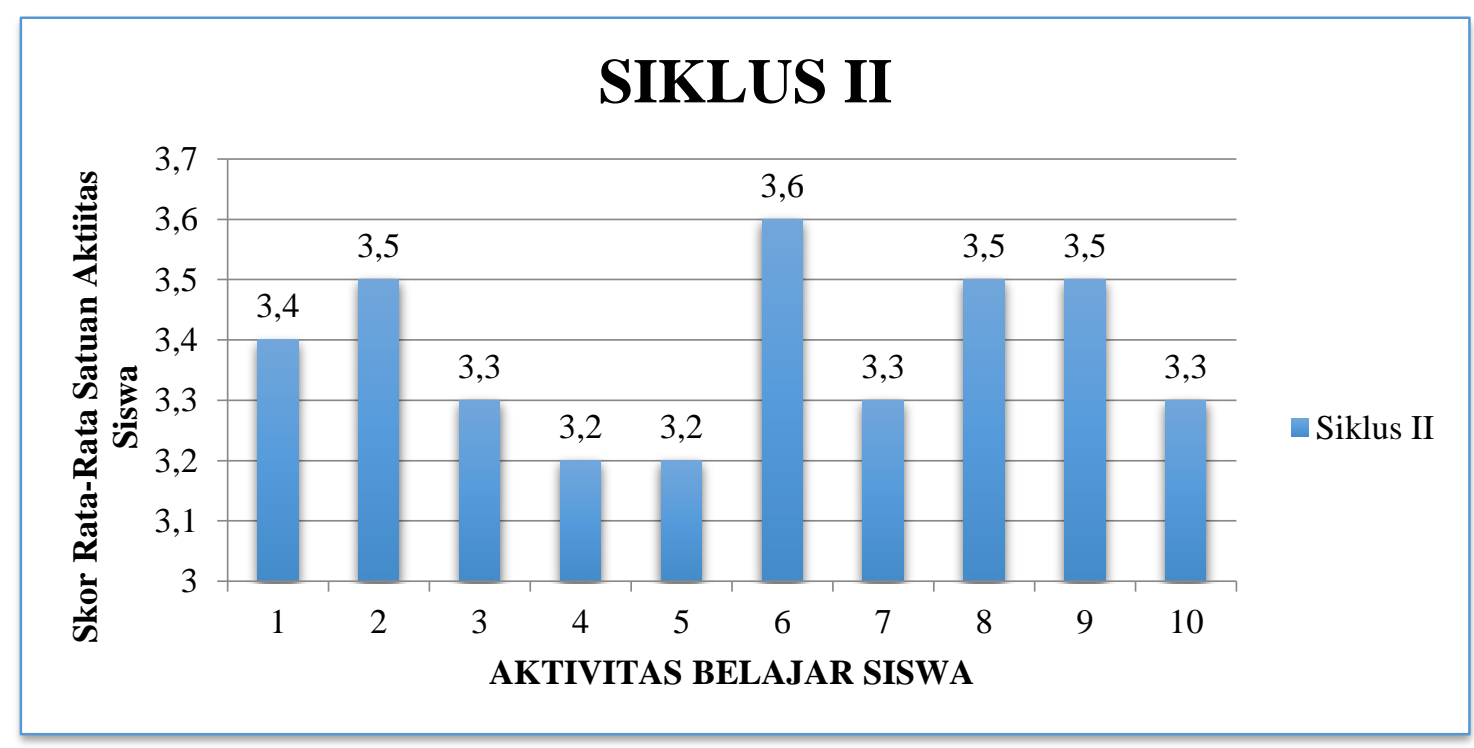

Gambar 3.7.Grafik Skor Rata-rata Satuan Aktivitas Belajar Siswa Siklus II 
Untuk mendapatkan gambaran rata-rata aktivitas belajar siswa selama pembelajaran pada siklusII pada pertemuan I dan II dapat dilihat pada gambar 3.8 berikut:

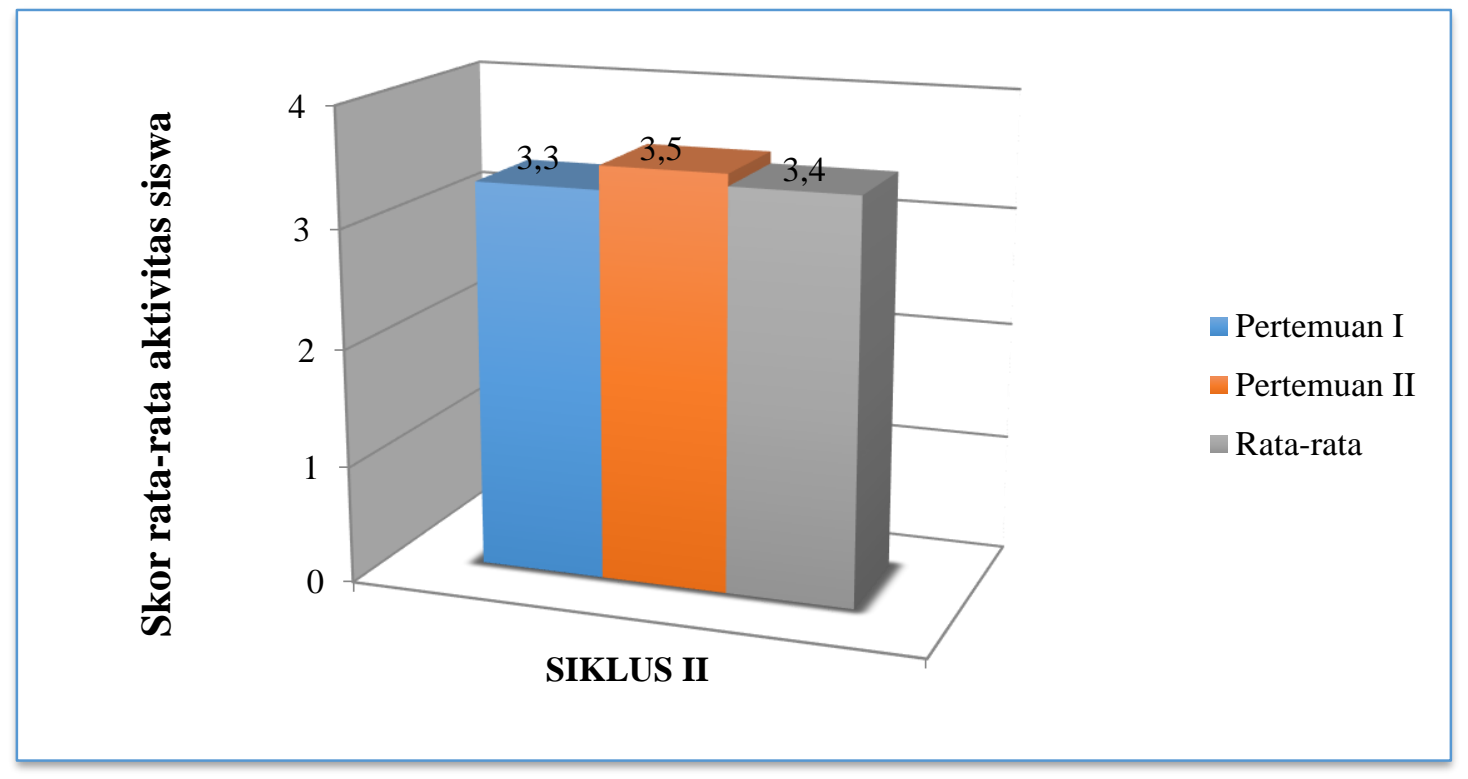

Gambar 3.8. Grafik Skor Rata-rata Aktivitas Belajar Siswa Siklus II

\section{Data Aktivitas Guru Siklus II}

Gambaran aktivitas guru dalam mengelola pembelajaran dengan menggunakan model pembelajaran generatif diperoleh dengan menggunakan lembar observasi aktivitas guru pada Siklus II dapat dilihat pada tabel 3.5berikut :

Tabel 3.5. Skor Rata-rata Aktivitas Guru Siklus II

\begin{tabular}{|c|c|c|c|c|}
\hline \multirow[b]{2}{*}{ No } & \multirow[b]{2}{*}{ Aspek Yang Dinilai } & \multicolumn{3}{|c|}{ Skor/Siklus II } \\
\hline & & Pert. I & Pert. II & $\begin{array}{l}\text { Rata- } \\
\text { Rata }\end{array}$ \\
\hline \multirow[t]{5}{*}{$\mathbf{1}$} & A. Kegiatan Pendahuluan & & & \\
\hline & $\begin{array}{l}\text { Guru membuka pelajaran dan } \\
\text { memeriksa kesiapan siswa }\end{array}$ & 4 & 4 & 4 \\
\hline & $\begin{array}{l}\text { 2. Guru menyampaikan indikator dan } \\
\text { tujuan pembelajaran }\end{array}$ & 4 & 4 & 4 \\
\hline & $\begin{array}{ll}\text { 3. Guru menyampaikan mengenai } \\
\text { model pembelajaran yang akan } \\
\text { dgunakan }\end{array}$ & 4 & 4 & 4 \\
\hline & $\begin{array}{l}\text { Guru memberikan apersepsi } \\
\text { tentang materi yang akan dipelajari }\end{array}$ & 4 & 4 & 4 \\
\hline
\end{tabular}


Jurnal Penelitian Pendidikan Geografi Volume 3 No. 1 Januari 2018

\section{B. Kegiatan Inti}

5. Guru menyajikan materi pelajaran

disertai dengan pertanyaanpertanyaan untuk mengkontruksi

$\begin{array}{lll}4 & 4 & 4\end{array}$ pengetahuan atau konsep awal siswa

6. Guru meminta siswa untuk mengemukakan ideatau gagasan terkait dengan materi yang akan

$\begin{array}{lll}3 & 4 & 3,5\end{array}$
dipelajari

7. Guru mengelompokan siswa menjadi 4 kelompok atau dikondisikan dengan cara meminta siswa menghitung 1,2,3, siswa yang menyebutkan angka 1 masuk

$\begin{array}{lll}4 & 4 & 4\end{array}$
dalam kelompok 1 dan begitu seterusnya

\begin{tabular}{lllll}
\hline 8. & $\begin{array}{l}\text { Guru memberikan lembar kerja } \\
\text { siswa (LKS) kepada masing- }\end{array}$ \\
masing kelompok dan menjelaskan & 3 & 4 & 3,5 \\
secara singkat tentang LKS yang \\
telah dibagikan
\end{tabular}


Jurnal Penelitian Pendidikan Geografi Volume 3 No. 1 Januari 2018

siswa untuk bertanya mengenai

materi yang kurang dimengerti

\section{C. Kegiatan Akhir}

3

3

16. Guru bersama sama menyimpulka 3

$\mathrm{n}$ materi yang telah dibahas

\begin{tabular}{ccccc}
\hline $\begin{array}{c}\text { 17. Guru memberikan PR terkait } \\
\text { dengan materi yang dipelajari }\end{array}$ & 3 & 3 & 3 \\
\hline
\end{tabular}

18. Guru menutup proses pembelajaran

$\begin{array}{lll}4 & 4 & 4\end{array}$

\begin{tabular}{lccc}
\hline Rata-rata aktivitas guru & 3,61 & 3,8 & 3,7 \\
\hline Kategori & & & Baik \\
\hline
\end{tabular}

Sumber: Data Diolah (2017)

Gambaran rata-rata aktivitas guru dengan menerapkan model pembelajaran generatif pada siklus II untuk setiap

satuan aktivitas yang dinilai dapat dilihat pada gambar 3.9 berikut:

\section{SIKLUS II}

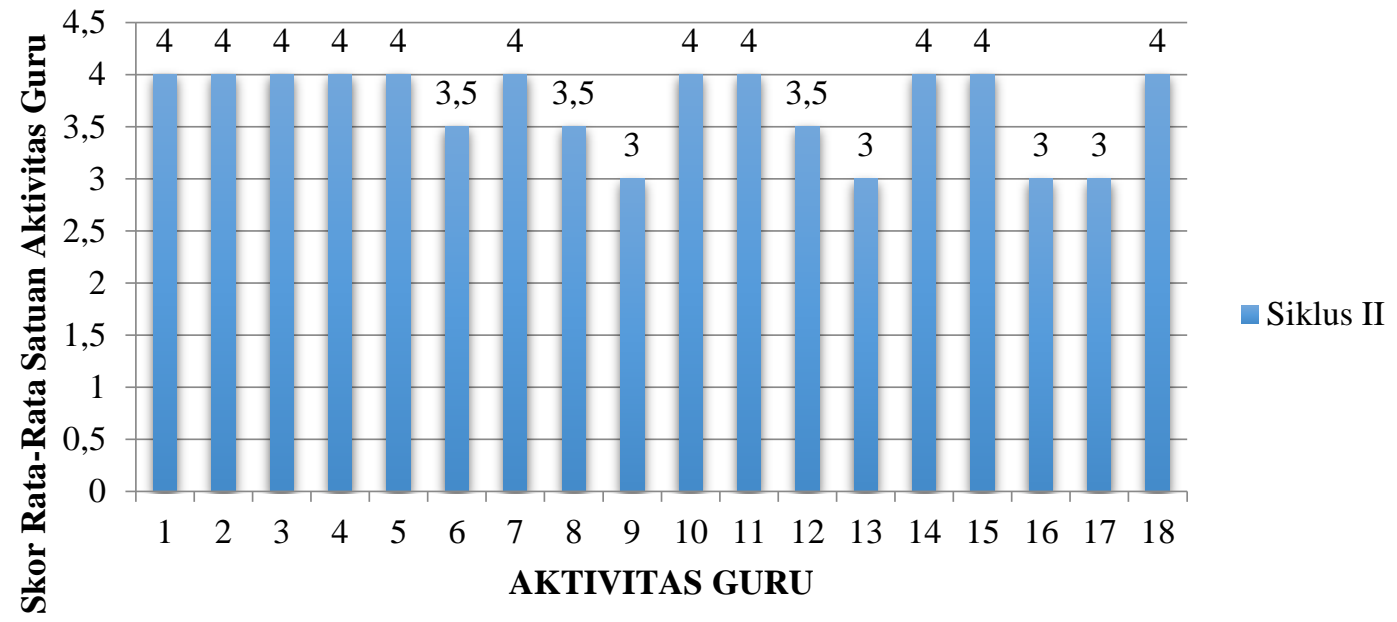

Gambar 3.9. Grafik Skor Rata-Rata Satuan Aktivitas Guru Siklus II

Untuk mendapatkan gambaran ratarata aktivitas guru selama pembelajaran pada siklus II pada pertemuan I dan II dapat dilihat pada Gambar 3.10 berikut: 
Jurnal Penelitian Pendidikan Geografi Volume 3 No. 1 Januari 2018

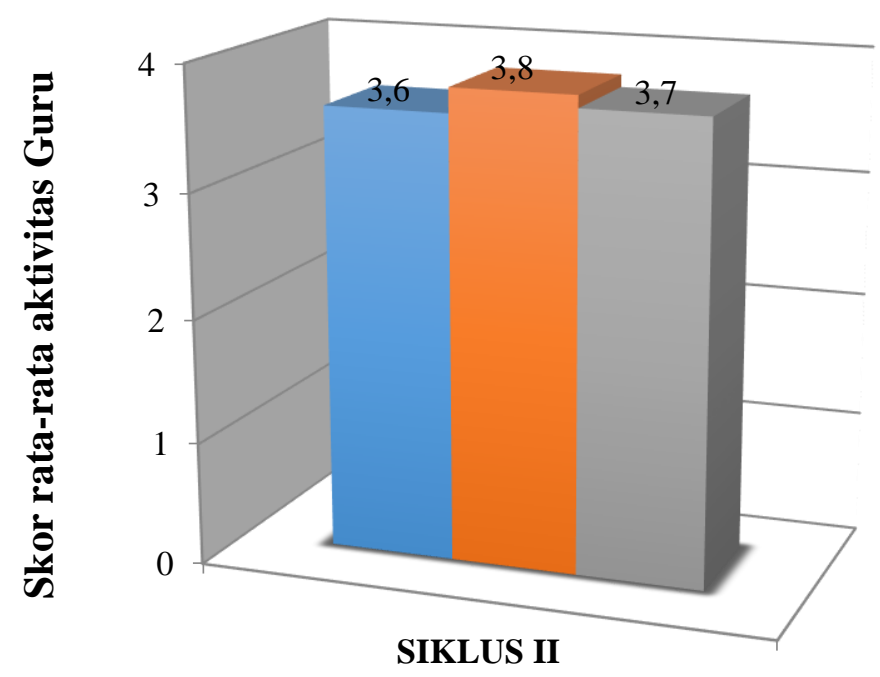

- Pertemuan I

- Pertemuan II

Rata-rata

Gambar 3.10. Grafik Skor Rata-rata Aktivitas Guru Siklus II

\section{Data Hasil Belajar Siswa Siklus II}

Berdasarkan hasil analisis data hasil belajar siswa pada siklus II diperoleh

hasil sebagaimana disajikan pada tabel 3.6 berikut :

Tabel 3.6. Data Analisis Ketuntasan Hasil Belajar Siswa Siklus II

\begin{tabular}{llcc}
\hline \multicolumn{1}{c}{ Skor } & Jumlah siswa & Presentase & Ketuntasan Belajar \\
\hline $0-69$ & 4 orang & $11 \%$ & Belum Tuntas \\
\hline $70-100$ & 32 orang & $89 \%$ & Sudah Tuntas \\
\hline Jumlah & 36 orang & $\mathbf{1 0 0 \%}$ & \\
\hline Keterangan $:$ & & & \\
\hline Tidak Tuntas & $\mathbf{: 4 ~ o r a n g}$ & \\
\hline Tuntas & $\mathbf{: 3 2}$ orang & \\
\hline Nilai Rata-rata & $\mathbf{: 8 2 , 3 6}$ & \\
\hline Nilai Maksimum & $\mathbf{: 1 0 0}$ & & \\
\hline Nilai Minimum & $\mathbf{: 6 0}$ & & \\
\hline Presentase Ketuntasan & $\mathbf{: 8 9 \%}$ & & \\
\hline
\end{tabular}

Sumber: Data Diolah (2017)

Untuk lebih jelasnya mengenai pembelajaran generatif pada siklus II gambaran hasil belajar siswa kelas X2 dapat dilihat pada gambar 3.11 berikut: yang diajar dengan menggunakan model 
Jurnal Penelitian Pendidikan Geografi Volume 3 No. 1 Januari 2018

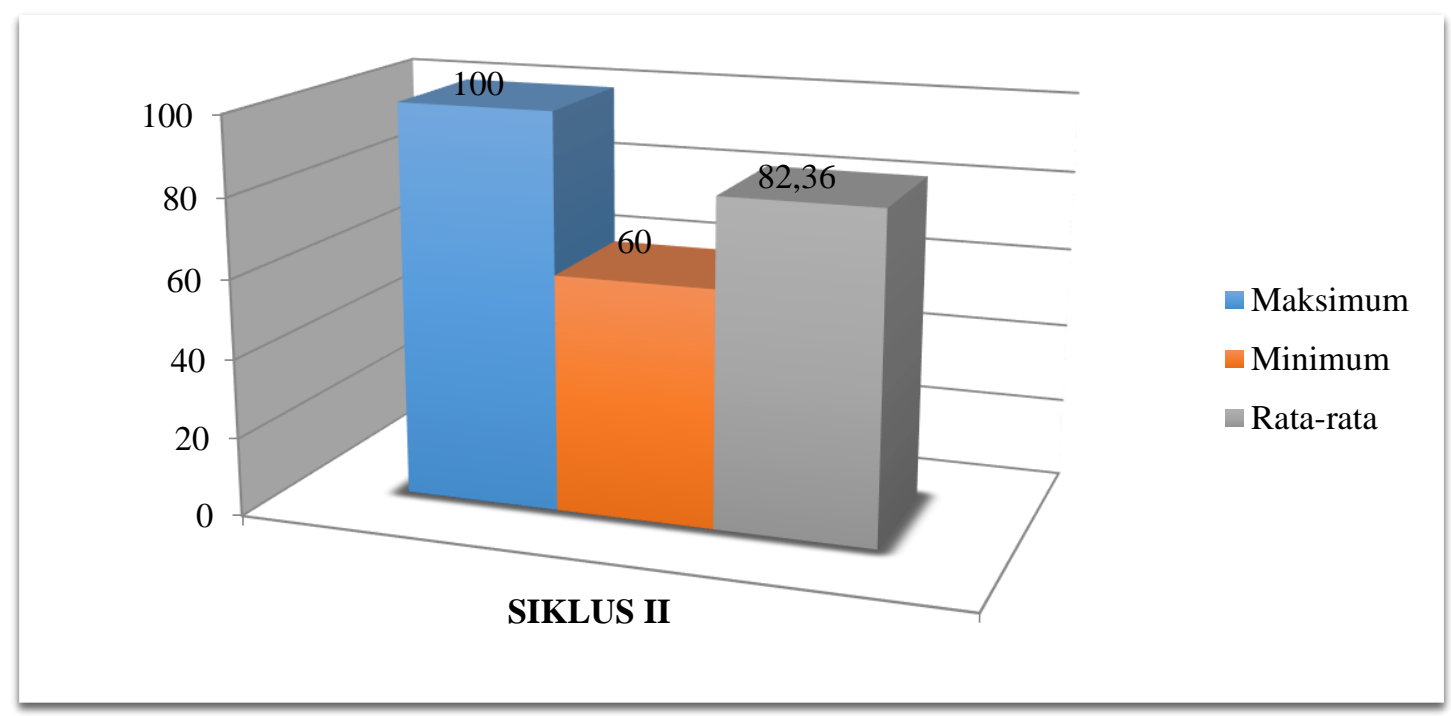

Gambar 3.11 Grafik Skor Rata-Rata Hasil Belajar Siswa Siklus II

Selanjutnya berdasarkan analisis ketuntasan belajar siswa pada siklus II diperoleh hasil sebagaimana disajikan pada gambar 3.12 berikut:

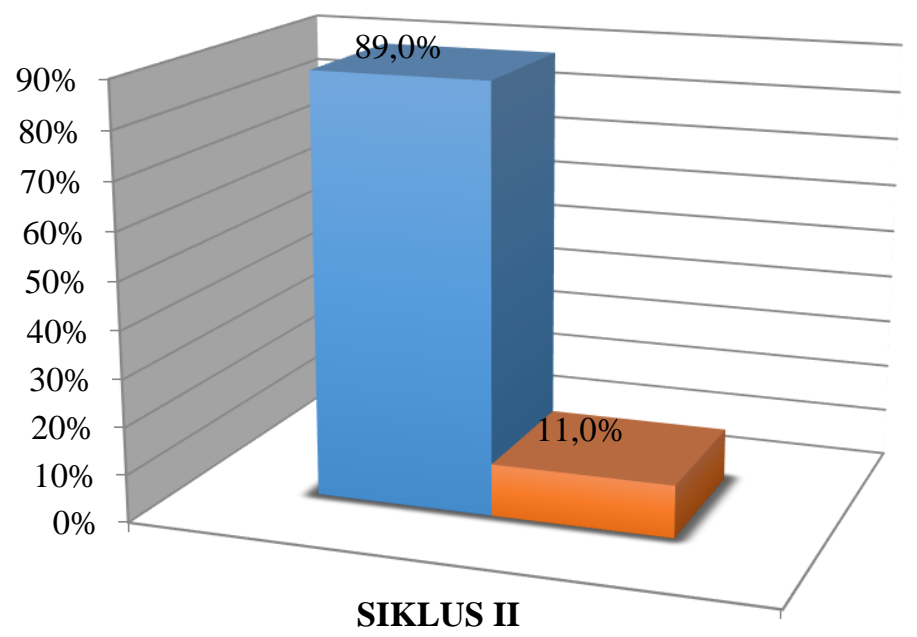

- Sudah Tuntas

Belum Tuntas

\section{Gambar 4.12. Grafik Presentase Ketuntasan Siswa Siklus II}

\section{PEMBAHASAN}

\section{Aktivitas Belajar Siswa selama KBM}

Berlangsung

Berdasarkan hasil refleksi pada siklus I ditemukan ada beberapa aktivitas siswa yang masih belum terlaksana dengan baik. Oleh karena itu dilakukan perbaikan pada siklus selanjutnya. Pada siklus II dari hasil analisis deskriptif terhadap skor rata-rata aktivitas belajar siswa pada siklus II menunjukkan adanya peningkatan yang signifikan dari aktivitas 
belajar siswa siklus I. dimana skor ratarata aktivitas belajar siswa pada siklus II sebesar 3,4 dengan kategori Baik. Hal ini menunujukan bahwa penelitian telah berhasil karena telah memenuhi standar minimal aktivitas siswa yaitu 3,0 .

\section{Aktivitas mengajar Guru}

Berdasarkan hasil refleksi terhadap aktivitas guru, dengan mengetahui kekurangan-kekurangan pada siklus I, guru memperbaiki cara mengajarkan materi pembelajaran yang sesuai dengan model pembelajaran generatif, sehingga diharapkan pada pertemuan selanjutnya diperoleh peningkatan aktivitas guru pada siklus selanjutnya.

Pada siklus II aktivitas mengajar guru menunjukkan peningkatan yang signifikan, dimana pada siklus II skor rata-rata aktivitas guru memperoleh nilai sebesar 3,7 yang berkategori baik. Hasil analisis dan pengamatan pada siklus II ini menunjukkan adanya peningkatan aktivitas guru dengan menerapkan model pembelajaran generatif. Hal ini menunujukan bahwa penelitian telah berhasil karena telah memenuhi standar minimal aktivitas mengajar guru yaitu 3,0 .

\section{Hasil Belajar Siswa}

Pada siklus I berdasarkan hasil tes hasil belajar siswa pada siklus I diperoleh nilai minimum sebesar 50; nilai maksimum 90; rata-rata hasil belajar siswa sebesar 72,63. Secara klasikal dari 36 siswa yang mencapai persentase ketuntasan hasil belajar yaitu 26 siswa atau $72,22 \%$ yang mencapai nilai $\geq 70$ sesuai dengan nilai KKM geografi dan terdapat 10 orang siswa dengan presentase sebesar $27,77 \%$ siswa yang nilainya belum mencapai KKM yang ditentukan oleh sekolah yaitu 70 . Presentase ketuntasan pada siklus I ini belum mencapai target peneliti yaitu mencapai ketuntasan belajar secara klasikal minimal 80\%.

\section{KESIMPULAN}

Berdasarkan hasil dalam penelitian ini dapat ditarik beberapa kesimpulan sebagai berikut: 1) gambaran aktivitas belajar siswa kelas X2 SMA Negeri 2 Kulisusu yang di ajarkan dengan model generatif pada setiap siklus cenderung meningkat. Hal ini ditunjukkan dengan skor rata-rata pada setiap siklus, dimana pada siklus I skor rata-rata aktivitas siswa adalah 2,8 yang termasuk kategori cukup, dan meningkat pada siklus II menjadi 3,4 yang berkategori baik, 2) gambaran aktivitas mengajar guru di kelas X2 SMA Negeri 2 Kulisusu yang di ajar dengan model pembelajaran generative pada setiap siklus cenderung meningkat.

Hal ini ditunjukkan dengan skor rata-rata pada setiap siklus, dimana pada siklus I skor rata-rata aktivitas guru adalah 2,9 yang termasuk kategori cukup dan meningkat pada siklus II menjadi 3,7 yang berkategori baik, 3) ada peningkatan hasil belajar geografi siswa kelas X2 SMA Negeri 2 Kulisusu yang diajar dengan model pembelajaran generatif. Dimana terdapat peningkatan sebesar $17 \%$ yang diperoleh dari hasil selisih antara persentase kentuntasan siklus IIdan siklus I. Hal ini dapat dilihat Pada siklus I, diperoleh nilai rata-rata hasil belajar 72,63 dengan persentase ketuntasan sebesar $72,2 \%$ yang mencapai KKM atau dari 36 siswa hanya 26 siswa yang memperoleh nilai $\geq 70$. Pada siklus II, diperoleh nilai rata-rata hasil belajar 82,36 dengan persentase ketuntasan sebesar $89 \%$ atau dari 36 orang siswa terdapat 32 orang siswa yang yang memperoleh nilai $\geq 70$ sesuai KKM yang ditetapkan sekolah. 
Jurnal Penelitian Pendidikan Geografi Volume 3 No. 1 Januari 2018

\section{DAFTAR PUSTAKA}

Arikunto, Suharsimi. 2006. Prosedur Penelitian Suatu Pendekatan Praktek. Jakarta: Rineka Cipta.

Hulukati, $\quad$ E. 2005. Mengembangkan Kemampuan Komunikasi dan Pemecahan Masalah Matematika Siswa SMP Melalui Model Pembelajaran Generatif.

Desertasi Program Doktor

Kependidikan dalam Pendidikan. 